\section{Chapter and verse}

SIR-Your reports on recent patents for invention of exceptional importance, and on actions before the British and US courts are extremely useful, but not one of them gives the all-important number of the patent under discussion. Consequently each report necessitates an often lengthy search before the actual patent specification can be studied.

All patent specifications can be found by their distinctive number and thereby easily isolated from the 30 million patent specifications held at the Science Reference Library in London. The search for US patents is made more difficult if the report fails to give not only the number but the full names of the inventors, as the US Patent Gazette, issued weekly, does not give the names of the assignees.

I give below, for the benefit of your readers, the numbers of the important patents to which your recent reports have referred:

(1) "The shadow over immunoassay", (Nature 340, 256; 1989) refers to US Patent 4376110 , in the names of Gary S. David and Howard E. Greene.

(2) "The settlement on AIDS" (326, 533; 1987) embraces US Patent 4520113 to Robert C. Gallo et al. of 1985 (not 1984).

(3) The AIDS envelope protein patent $(331,649 ; 1988)$ is US 4725669 to Myron Essex and Tun-Hou Lee. There is a corresponding European patent application 201588.

(4) The first-ever animal patent issued in the United States $(332,668 ; 1988$ \& 338, $366 ; 1989)$ is 4736866 to Philip Leder and Timothy Stewart. The corresponding European patent application is 169672 . Each refers to Nature 294, 92-94 (1981) as pertinent prior art, namely the article by F. Costantine and E. Lacy "Introduction of a rabbit $\beta$ globin gene into the mouse germ line". US Patent Classification List Class 800-1 records about 50 earlier US patents, all directed to multicellular living organisms and unmodified parts thereof.

(5) The first US patent on TPA for Oxford University $(\mathbf{3 3 3}, 383 ; 1988)$ is 4751084 to Joseph Feder, William R. Tolbert, Thomas W. Rademacher, Raj B. Parekh and Raymond A. Dwek. The corresponding European patent application is 236289 . The Genentech British patent application declared invalid (see Report of Patent Cases 1987 (24) p.553-589) is 2119804 and the corresponding US patent 4766075 .

(6) The US patent involving T7 DNA polymerase-based sequencing technology developed at Harvard by inventors Stanley Tabor and Charles C. Richardson (340, $418 ; 1989$ ) is US 4795699.

(7) The first US patent for superconductors, to Vander Sande and Gregory J. Yurek $(336,607 ; 1988)$ is US 4826808 . (It was not reported in the US Patent Gazette until 2 May 1989, thereby requiring some 23 weeks of search.)

(8) The US patent for Montagnier, directed to HIV-2 $(\mathbf{3 4 0}, 253 ; 1989)$ is US 4839288.

Frank W. Cousins

43 Emanuel House,

18 Rochester Row,

London SW1P 1BS, UK

\section{Missing formula}

SIR-V. A. Huszagh and J.P. Infante's Commentary (Nature 338, 109; 1989) refers to one of the basic problems that inhibit the growth of knowledge in biological sciences: the uncritical accumulation of vast amounts of unconnected data arising from experiments that do not depend on any clearly formulated hypothesis.

Although the authors deserve merit for defining the problem, they do not go far enough in seeking an answer. The examples cited clearly indicate that theoretical solutions in biology are possible only if mathematical methods of another, more basic science fit the problem. Thus, in contrast to physics or even chemistry, biology by itself may be called an incomplete, that is exclusively experimental, science.

Until now, no serious attempts have been made to adapt mathematical logic to biology. Biology therefore lacks both exact principles such as axioms as well as a strictly logical superstructure.

Biologists see the complexity of biology as the only major hindering factor that prevents mathematics from becoming its appropriate theoretical frame. But this impediment might be overcome if there were not a second factor: the participating scientists themselves. Apparently, most of them look upon mathematics as a subject of philosophy - and philosophy is not in their sphere of interest.

University of Mainz,

Department of Pediatrics,

Laboratory of Immunology,

Langenbeckstrasse 1 ,

D-6500 Mainz 1, FRG

\section{What's in a name?}

SiR--Your recent suggestion (Nature 341, $89 ; 1989)$ that every member state of the European Communities should have two currencies, its own and the ECU, makes good sense, but it needs one important amendment. Governments for centuries have understood the need to associate bold images with their monetary units. And what image does the ECU suggest? An infinity of small grey men in small cubicles inhabiting the largest grey building in the world.
But what if we name our unit the Einstein? Or, since shortening and initialization is the order of the day, how about 1 Sks for Shakespeare, or 1 Rem for Rembrandt, or 1 Ps for Pasteur, or $1 \mathrm{Vr}$ for Verdi, or 1 Ri for Riemann?

One could believe that a decision over which particular name to choose would cause great argument, sufficient to disrupt more than one European summit. But the need also to name the various multiples of the primary unit would accommodate quite a few great names. And for the primary unit itself there is one special name that might well recommend itself to everybody, partly from a sense of irony and partly as a much-needed retribution. So let the primary unit be named after someone whom the world of his own day buried in a pauper's grave. Let it be $1 \mathrm{Mz}$ for Mozart.

A sensibly named currency would of course soon drive out national currencies on a European scale. But would it not also drive out other currencies worldwide? For who would want to carry dull dollars in their wallets when they could be carrying Mozarts? I ask you.

102 Admiral's Walk

FRED HOYLE

West Cliff,

Bournemouth BH25 1TF, UK

SiR-In your leading article entitled "Funny money" (Nature 340, 580; 1989) you did not address the matter of its physical form. I suggest that consideration be given to replacing paper money by plastic or plasticized paper, of a size and shape like those of credit cards but thinner.

Cards should be washable, of standard weight and colour-coded. (Perhaps US notes are the only ones that still lack this feature.) They could have various metal strips to make them easily acceptable, distinguishable, sortable and countable in machines (for parking meters, telephone boxes, bus/train tickets, change, and so on). Suitably disposed fenestrae or notches could help the blind as well as the machines. Incorporation of specific diatom shells could add an unforgeable forensic feature, as could fluorescent threads

Denominations could be variously printed for different countries (for example, red: 1 Eurobuck $=\mathrm{DM} 2=\mathrm{FFr} 2=$ $1,000 \mathrm{IL}$ ) on one side; on the reverse, the international value would be indicated in Esperanto. There would be no religious symbols or slogans in any text. If and when necessary, changes could be embossed.

Paper money is dirty and ephemeral: it is time we evolved better things.

RALPH A. LEWIN

Scripps Institution of Oceanography,

University of California, San Diego,

La Jolla,

California 92093, USA 